\title{
Research and Development of Test Rig Prototype for Remanufactured Automatic Transmission
}

\author{
J. Ma, Q.C. Wang, Q. Chen \\ Institute of Vehicle Engineering \\ Zhejiang University of Technology \\ China
}

\begin{abstract}
The paper puts forward a new model of electric-loading test rig for testing remanufacture automatic transmission to meet the demands for testing different types of remanufactured automatic transmissions. The sub-systems, including electric \& electronic control systems and the mechanical components, were developed for the test rig. Especially, the mounting panel for power transmission system was designed to match the different types of automatic transmission cases and hydraulic torque converters. And the prototype of the electric-loading test rig was completed for testing remanufactured automatic transmission. The performances of the test rig prototype were validated in the case of testing the Volkswagen $01 \mathrm{M}$ model of remanufactured automatic transmission.
\end{abstract} $R \& D$

Keywords-remanufacturing; automatic transmission; test rig;

\section{INTRODUCTION}

It is necessary to validate the functions of remanufactured automatic transmissions to check whether they meet practical requirements. There are two ways to detect an automatic transmission without disassembling it: rig test and road test [1]. Rig test usually be used to test working performance of mechanic, hydraulic and solenoid valve of a remanufactured automatic transmission. Compared to road test, rig test saves time and energy, and requires less experiment conditions, thus it is more suitable for companies to detect automatic transmissions. Remanufactured automatic transmissions come from different OEMs with various models and obvious structure differences in different remanufacturing companies. At present, the rarely kind of transmission test rig is of versatile functions to test different kinds of remanufactured automatic transmission, especially for different brands and various models of automatic transmissions [2]. Therefore, it is a necessity to develop a test rig for remanufactured automatic transmissions, which meets the requirements of remanufacturing detection and has good versatility at the same time.

\section{GENERAL SCHEME AND TECHNICAL PRINCIPLE OF TEST RIG}

This test rig is made of an open loop power control with advantages of simple structure, reliable operation, little space occupation and good generality, fig. 1. But it's with disadvantages of high energy consumption. In consideration to shorten R\&D time and actual conditions, the type of open loop power test rig is more suitable for different remanufacturing companies.

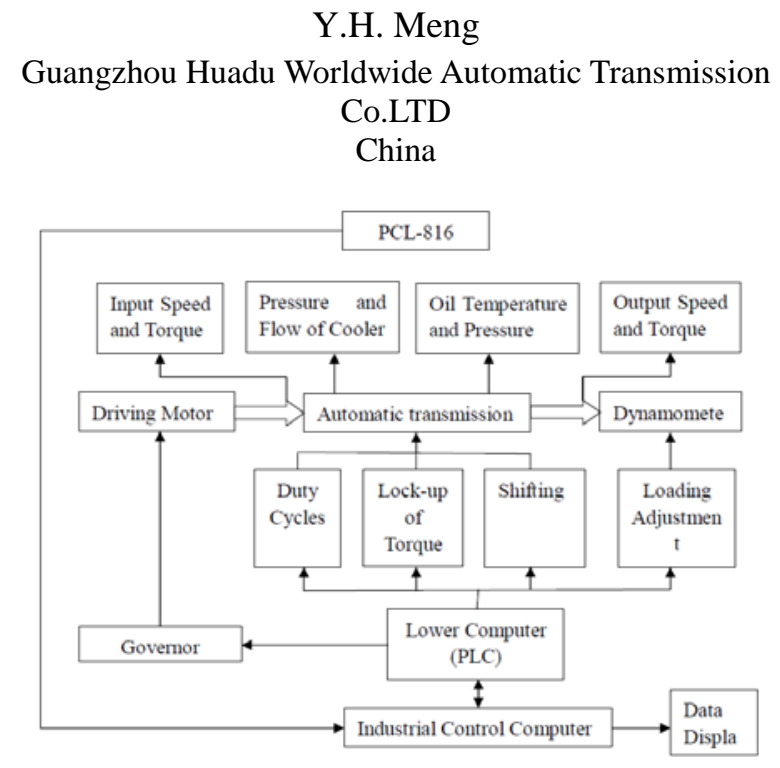

FIGURE I. FRAME OF TEST RIG FOR REMANUFACTURED AUTOMATIC TRANSMISSION

III. SUB-SYSTEM OF TEST RIG

A. General Layout of Mechanical System

Mechanical system of test rig consists of frame, transmission system, dynamic system and dynamometers, fig. 2. Clamping platform and load motor are allowed to move in certain extent, so as to mount different type of automatic transmission. Fig. 2 shows the mounting way of automatic transmission for FF and transverse engines. And this test rig also can mount other two kinds of transmission by adjusting the clamping platform and load motor. Fig. 3 shows the mounting way of the other two kinds of transmission.

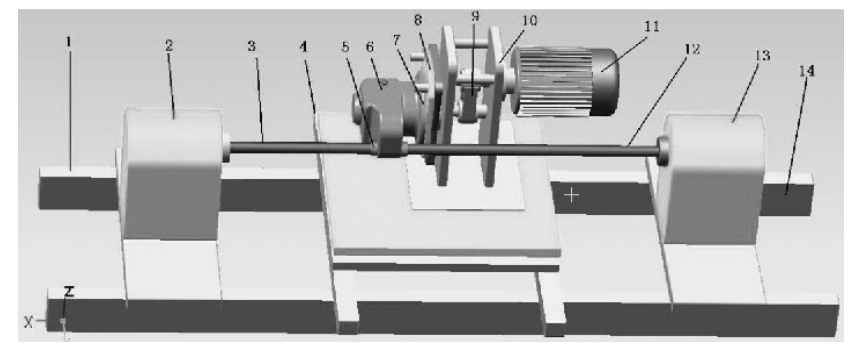

1. main guide; 2\&13. dynamometer; 3\&12. output shafts; 4. clamping platform; 5. shaft heads; 6. remanufactured transmission; 7. mounting panel for torque converters; 8. mounting panel for case; 9. pulley drive; 10. mounting panel for motor; 11 . drive motor; 14 . frame

FIGURE II. MECHANICAL SYSTEM OF TEST RIG 


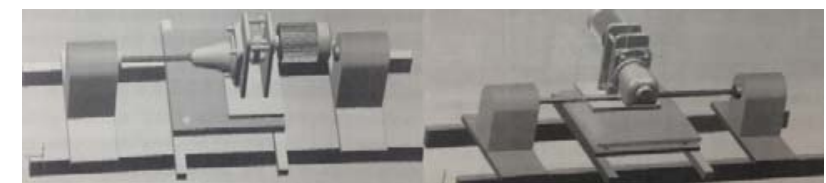

a. layout of automatic transmission of fr or four-drive vehicle

b. layout of automatic transmission of $\mathrm{ff} \&$ longtitudinal engine mounting vehicle

FIGURE III. LAYOUT OF AUTOMATIC TRANSMISSION ON TEST RIG

\section{B. Transmission System}

There are different kinds of positions and dimension of connecting holes of cases and hydraulic torque for different brands of transmissions. A set of general mounting panel is designed for different cases and hydraulic torque converters.

The mounting dimension of cases of various models of automatic transmissions is measuring and the similar connecting holes are arranged in the same mounting panel, on which several rows of connecting holes are arranged. Fig. 4.a shows the mounting panel for cases.

Different of output shafts were designed for different kinds of output shaft heads of automatic transmissions, fig. 4.b.

The bolts of hydraulic torque converters are usually of different amount and centre distances. There are mainly three kinds of distribution forms: three bolts, four bolts or six bolts. Fig 4.c shows a general mounting panel which can match all distributions above even several particular distributions.

\section{Power System}

The variable-frequency motor is selected as power source in this test rig. Power was transferred to input shaft through pulley drive which could alleviate the shock from shift process. Considering the overload test is not needed, the motor power of test rig is chosen as $10 \%$ of car power. For most of car power was above $200 \mathrm{Kw}$, the motor power is selected $22 \mathrm{Kw}$.

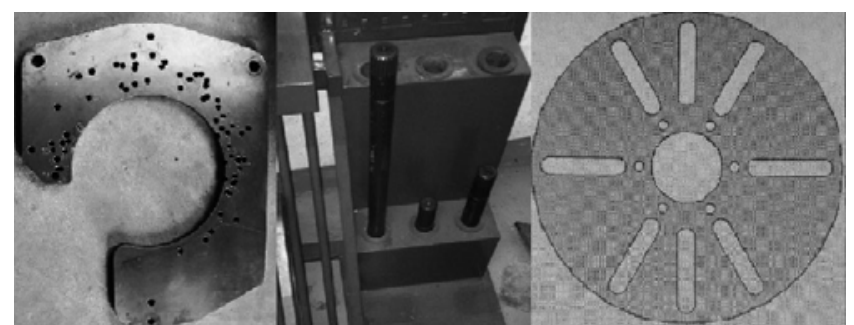

A. MOUNTING PANEL FOR CASES

B. OUTPUT SHAFTS

C. MOUNTING PANEL FOR TORQUE CONVERTERS

FIGURE IV.MOUNTING PANEL \& OUTPUT SHAFTS

\section{Dynamometer}

Eddy current dynamometer is chosen for this test rig with PID control system that is of two control modes: constant speed control and constant torque control.

\section{E. Measurement and control system}

There are functions of data acquisition and signal processing system in the measurement and control system. The real time measurement to automatic transmission through sensors and detection device are carries out [3]. Industrial control computer and Siemens S7-200 are the core of measurement and control system. Data is collected by PCL-816 and transferred to industrial control computer through RS-485.

\section{THE FUNCTION OF TEST RIG}

More than thirty-six types and several hundred models of automatic transmissions can be test in the test rig. Some typical brands of automatic transmissions that can be test are shown in table 1 and testing items of test rig that can be done are shown in table 2. Table 3 shows the output data of automatic transmissions through indicator of the test rig.

TABLEI. SOME TYPICAL MODELS OF AUTOMATIC TRANSMISSIONS

\begin{tabular}{|c|c|c|c|c|c|}
\hline No. & Models & No. & Models & No. & Models \\
\hline 1 & $01 \mathrm{M} / \mathrm{N}$ & 5 & RE0F10A & 9 & 03-71L \\
\hline 2 & $4 \mathrm{~T} 65 \mathrm{E}$ & 6 & JATCO RE4 & 10 & $01 \mathrm{~J}$ \\
\hline 3 & AL4 & 7 & $4 \mathrm{~L} 3 \mathrm{E}$ & 11 & $4 \mathrm{HP} 18$ \\
\hline 4 & 722.6 & 8 & AX4S & 12 & B7XA \\
\hline
\end{tabular}

TABLEII. TEST ITEMS OF TEST RIG

\begin{tabular}{|c|c|}
\hline No. & Test items \\
\hline 1 & Input-output real-time rotate speed and torque \\
\hline 2 & Real-time pressure and flow of cooler \\
\hline 3 & $\begin{array}{c}\text { Oil pressure and oil temperature in oil circuit based on } \\
\text { specified rotation of gears positions }\end{array}$ \\
\hline 4 & Lag test while shifting and function test of forward gear \\
\hline 5 & $\begin{array}{c}\text { Test of the lockup clutch control of hydraulic torque converter } \\
\text { and electromagnetic valve }\end{array}$ \\
\hline
\end{tabular}

TABLEIII. OUTPUT DATA OF AUTOMATIC TRANSMISSIONS

\begin{tabular}{|c|c|}
\hline No. & Output data \\
\hline 1 & Input-output speed of gears positions \\
\hline 2 & Main oil pressure based on different loads \\
\hline 3 & Coolant flow, pressure \\
\hline 4 & Lag time of gears positions \\
\hline 5 & The test curve of forward gear \\
\hline
\end{tabular}

\section{TEST CASE OF REMANUFACTURED AUTOMATIC TRANSMISSION}

The remanufactured four-speed electronic automatic transmission Volkswagen $01 \mathrm{M}$ is tested as a case in this test rig. The problem of slow shifting and low oil pressure is tested in the remanufactured Volkswagen 01M. Fig. 5 shows the test site of Volkswagen 01M transmission after remanufactured. The output data are shown in fig. 6, table 4 and table 5 . 
TABLEIV. TEST RESULTS OF 01M.

\begin{tabular}{|c|c|c|c|c|c|c|c|c|}
\hline \multirow{2}{*}{$\begin{array}{l}\text { Shif } \\
\text { t }\end{array}$} & \multirow{2}{*}{$\begin{array}{c}\text { Mai } \\
\text { n } \\
\text { spee } \\
\text { d } \\
\text { (rp } \\
\text { m) }\end{array}$} & \multirow{2}{*}{$\begin{array}{c}\text { Rig } \\
\text { ht } \\
\text { spee } \\
\text { d } \\
\text { (rp } \\
\text { m) }\end{array}$} & \multirow{2}{*}{$\begin{array}{l}\text { Left } \\
\text { speed } \\
(\text { rpm) }\end{array}$} & \multicolumn{3}{|c|}{$\begin{array}{c}\text { Main } \\
\text { pressure(psi) }\end{array}$} & \multirow{2}{*}{$\begin{array}{c}\text { Flow of } \\
\text { coolant } \\
(\mathrm{L} / \mathrm{min} \\
)\end{array}$} & \multirow{2}{*}{$\begin{array}{c}\text { Pressu } \\
\text { re of } \\
\text { coolan } \\
\text { t } \\
\text { (psi) }\end{array}$} \\
\hline & & & & $\begin{array}{l}20 \\
\%\end{array}$ & $\begin{array}{l}40 \\
\%\end{array}$ & $\begin{array}{l}65 \\
\%\end{array}$ & & \\
\hline $\mathrm{P}$ & 799 & 0 & 0 & 55 & 51 & 36 & 1.1 & 29 \\
\hline $\mathrm{R}$ & $\begin{array}{c}150 \\
2\end{array}$ & 145 & 145 & $\begin{array}{c}17 \\
9\end{array}$ & $\begin{array}{c}18 \\
0\end{array}$ & $\begin{array}{c}11 \\
8\end{array}$ & 0.6 & 42 \\
\hline $\mathrm{N}$ & 799 & 0 & 0 & 59 & 59 & 60 & 0.1 & 22 \\
\hline D1 & $\begin{array}{c}180 \\
0\end{array}$ & 186 & 186 & $\begin{array}{c}15 \\
6\end{array}$ & $\begin{array}{c}11 \\
1\end{array}$ & 71 & 4.0 & 87 \\
\hline
\end{tabular}

TABLEV. SHIFTING TIME OF FORWARD GEAR OF 01M

\begin{tabular}{|c|c|c|c|c|c|}
\hline Shifting & D1-D2 & D2-D3 & D3-D4 & D3-D2 & D2-D1 \\
\hline Time(ms) & 340 & 270 & 200 & 550 & 550 \\
\hline
\end{tabular}

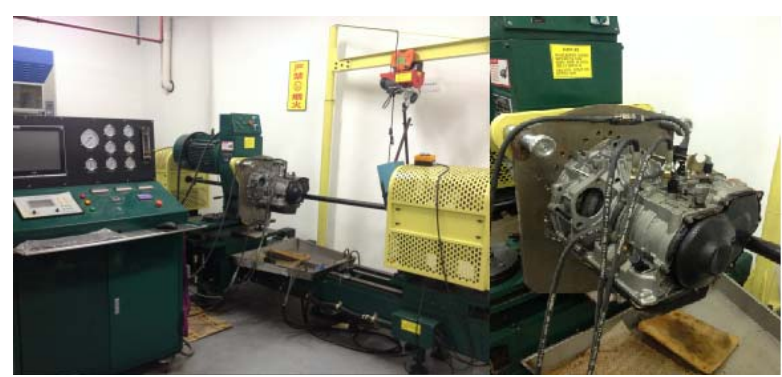

FIGURE V. TEST SITE OF VOLKSWAGEN 01M

Compared with the original properties of $01 \mathrm{M}$, this remanufactured transmission meets the requirement of practice usage [4].

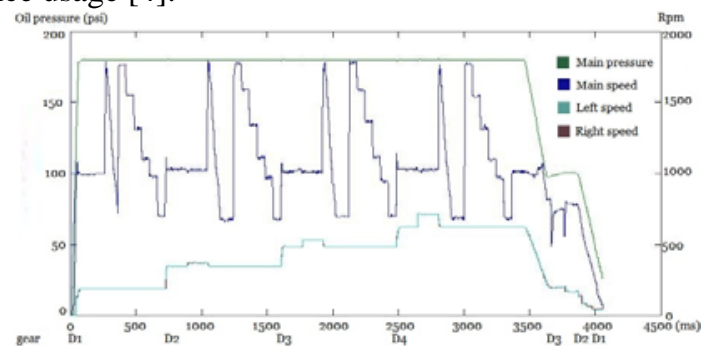

FIGURE VI.FIGURE VI. SHIFT CURVE TESTED OF 01M TRANSMISSION

\section{CONCLUSION}

A new test rig is designed and developed for remanufactured automatic transmissions with the advantages of high degree of automation, versatility, efficiency and precision, in which most automatic transmissions with various brands can be test. The function and reliability of the test rig is validated through experimentation in the case of $01 \mathrm{M}$ remanufactured automatic transmission .The test rig can meet the practical needs of different automatic transmission remanufacture companies and provides a platform with more safety and reliability for automatic transmission performance test, with great potentiality to improve production efficiency of automatic transmission remanufacturing.

\section{ACKNOWLEDGEMENTS}

This research work is supported by Zhejiang Provincial Natural Science Foundation of China (Grant No. LZ12E05003) and Zhejiang Provincial Qianjiang Talents Program (Grant No.2013R10058).

\section{REFERENCES}

[1] Jie Gong, Dingxuan Zhao, Ying Chen, et al., Study on shift schedule saving energy of automatic transmission of ground vehicles. Journal of Zhejiang University Science, 5(7), pp. 878-883, 2004.

[2] Jinming Zhang, Qiong Lin, \& Qiucheng Wang, Research of remanufacturing test rig for used automatic transmission. Machinery, 1, pp. 54-56, 2011.

[3] Qiong Lin, Zhonghao Dai, \& Bin Meng, Fault detection and experiment research of remanufacturing automatic transmission based on BP neural network. 2011 International Conference On Electrical and Control Engineering (ICECE), IEEE, pp. 191-194, 2011.

[4] Zhiwei Li, Mingfu You, \& Qiang Wen., Analysis of the Shift Process and Design Thought of 01M Automatic Transmission based on Lever Method. Journal of Mechanical Transmission, 10, pp. 030, 2011. 